\title{
PRODUCTION OF EXTRACELLULAR LIPASE BY THE PHYTOPATHOGENIC FUNGUS FUSARIUM SOLANI FS1
}

\author{
Maria de Mascena Diniz Maia ${ }^{1}$; Marcia Maria Camargo de Morais ${ }^{2}$; Marcos Antonio de Morais \\ Jr. $^{3}$; Eduardo Henrique Magalhães Melo²; José Luiz de Lima Filho ${ }^{2 *}$
}

${ }^{1}$ Departamento de Biologia, Universidade Federal Rural de Pernambuco, Recife, PE; ${ }^{2}$ Setor de Biotecnologia - LIKA, ${ }^{3}$ Departamento de Genética, Universidade Federal de Pernambuco - UFPE, Recife, PE, Brasil

\begin{abstract}
A Brazilian strain of Fusarium solani was tested for extracellular lipase production in peptone-olive oil medium. The fungus produced 10,500 U.L-1 of lipase after 72 hours of cultivation at $25^{\circ} \mathrm{C}$ in shake-flask at $120 \mathrm{rpm}$ in a medium containing $3 \%(\mathrm{w} /$ v) peptone plus $0.5 \%(\mathrm{v} / \mathrm{v})$ olive oil. Glucose $(1 \% \mathrm{w} / \mathrm{v})$ was found to inhibit the inductive effect of olive oil. Peptone concentrations below 3\% (w/v) resulted in a reduced lipase production while increased olive oil concentration (above $0.5 \%$ ) did not further stimulate lipase production. The optimum lipase activity was achieved at $\mathrm{pH} 8.6$ and $30^{\circ} \mathrm{C}$ and a good enzyme stability ( $80 \%$ activity retention) was observed at $\mathrm{pH}$ ranging from 7.6 to 8.6 , and the activity rapidly dropped at temperatures above $50^{\circ} \mathrm{C}$. Lipase activity was stimulated by the addition of $n$-hexane to the culture medium supernatants, in contrast to incubation with water-soluble solvents.
\end{abstract}

Key words: Enzyme kinetics, ester hydrolysis, extracellular lipase, Fusarium solani

\section{INTRODUCTION}

Lipases (triacylglycerol acylhydrolases E. C. 3.1.1.3) are enzymes that hydrolyse fatty acyl ester bonds of acylglycerols at the interface between oil and water (2). In organic medium, lipases are able to catalyse reactions of synthesis and transesterification of glycerides and phosphoglycerides, as well as a variety of non-glyceride, ester bonds $(2,9,18,22)$. Lipases have been extensively studied because of their actual and potential applications in the detergent, oil and food industries. Recently, various strategies in the pharmaceutical and chemical industries have used lipases in the synthesis of optically pure drugs and agrochemicals that are more effective and produce fewer side effects compared with their racemates $(11,22)$. Fungi are preferable lipase sources because fungal enzymes are usually excreted extracellularly, facilitating extraction from fermentation media. The selectivity of lipases has been exploited in industry in the synthesis of chiral compounds as well as in the resolution of racemic mixtures (19). The production of lipase by several Fusarium oxysporum strains has been studied in terms of enzyme production, protein properties and purification $(7,8,11)$. The aim of this work was to describe the production of an extracellular lipase by a Fusarium solani FS1 isolated from Carica papaya fruit.

\footnotetext{
* Corresponding author. Mailing address: Setor de Biotecnologia - LIKA, UFPE, Av. Moraes Rego, S/N, CEP 50732-901, Recife, PE, Brasil. Fax: (+5581) 271-8485. E-mail: 62j1lf@npd.ufpe.br
} 


\section{MATERIALS AND METHODS}

Microorganism: Fusarium solani FS1 was obtained from the culture collection of the Plant Health Department of the Federal Rural University of Pernambuco. The cultures were maintained at $4^{\circ} \mathrm{C}$ on potato dextrose agar plates.

Growth conditions: Fusarium solani FS1 was batch cultivated in a basal medium (BM) $\mathrm{pH} 6.0$ consisting of (g. $\mathrm{L}^{-1}$ of deionized water): $\mathrm{MgSO}_{4} .7$ $\mathrm{H}_{2} \mathrm{O}, 0.5 ; \mathrm{KH}_{2} \mathrm{PO}_{4}, 1 ; \mathrm{NaNO}_{3}, 3$; peptone, 30. It was supplemented with different carbon sources (glucose, olive oil and peptone). Pre-inoculum consisted of $10^{5}$ spores incubated in $10 \mathrm{ml}$ of BM in a rotary shaker $(120 \mathrm{rpm})$ for 2 days at $28^{\circ} \mathrm{C}$. After this time, a $500 \mathrm{ml}$ flask containing $90 \mathrm{ml}$ of $\mathrm{BM}$ was inoculated with the pre-inoculum and cultivated as above. Aliquots of $10 \mathrm{ml}$ of this culture were withdrawn at different periods of incubation and centrifuged. The supernatants were used to measure lipase activity, protease activity and $\mathrm{pH}$. The pellet was washed in water, filtered and dried in preweighed filters for biomass determination. Peptone and oil concentrations varied as shown in results. The results were calculated from three independent cultures. Each measurement was carried out in triplicate.

Enzyme assay: Lipase activities were assayed in the enzyme-containing supernatants with $\mathrm{p}$ nitrophenyl palmitate (pNPP) as substrate determined spectrophotometrically at $410 \mathrm{~nm}$ (23). One lipase unit $(\mathrm{U})$ is defined as the amount of enzyme that liberated $1 \mu \mathrm{mol}$ p-nitrophenol per minute. Protease in the supernatant was measured according to Ginther (5) using azocasein as substrate. One unit of protease activity is defined as the amount of enzyme that produces na increase in absorbance of 1.0 in $1 \mathrm{~h}$ at $440 \mathrm{~nm}$.

Effect of pH and temperature toward pNPP: The $\mathrm{pH}$ values of the reaction mixtures were varied from 5.4 to 7.8 (in $50 \mathrm{mM}$ tris-maleate) and 8.0 to 8.8 (in $50 \mathrm{mM}$ tris- $\mathrm{HCl}$ ) and lipase activity was measured at $25^{\circ} \mathrm{C}$. To determine the $\mathrm{pH}$ stability, lipase-containing supernatant was diluted 1:1 in 100 $\mathrm{mM}$ of the buffers described above and incubated for one hour at $25^{\circ} \mathrm{C}$ before assayed. Lipase activities were assayed in reaction mixtures of pNPP containing tris- $\mathrm{HCl} \mathrm{pH} 8.0$ at a range of temperatures from $15^{\circ} \mathrm{C}$ to $60^{\circ} \mathrm{C}$ to determine optimum lipase activity. For thermal stability, lipase-containing supernatants were pre-incubated for 60 minutes over a range of temperature from $25^{\circ} \mathrm{C}$ to $50^{\circ} \mathrm{C}$ in tris$\mathrm{HCl} \mathrm{pH} 8.0$ buffer. After this time, the mixtures were left for 10 minutes at room temperature and lipase activity were measured using the standard procedure.

Effect of organic solvents: The supernatant was diluted with organic solvents in the concentrations of 0 to $50 \%(\mathrm{v} / \mathrm{v})$. After 1 hour of incubation with constant shaking at $25^{\circ} \mathrm{C}$, lipase activity was measured in the aqueous phase as described above.

\section{RESULTS AND DISCUSSION}

\section{Effect of the medium composition on lipase activity}

The activity of extracellular lipase of $F$. solani FS1 cultures was evaluated after 96 hours of incubation in medium containing $3 \%(\mathrm{w} / \mathrm{v})$ peptone alone and supplemented with different carbon sources (Table 1). Highest lipase activity of 9,500 U.L ${ }^{-1}$ was observed in the medium containing $1 \%$ olive oil.This represents an 8 -fold lipase induction

Table 1. Effect of the carbon source on production of lipase activity by FS1 after 96h cultivation.

\begin{tabular}{ccccc}
\hline $\begin{array}{c}\text { Additional carbon } \\
\text { source } \\
{[1 \%(\mathrm{w} / \mathrm{v})]}\end{array}$ & $\begin{array}{c}\text { Maximum lipase } \\
\text { activity }\left(\mathrm{U} . \mathrm{L}^{-1}\right)\end{array}$ & $\begin{array}{c}\text { Maximum mycelial } \\
\text { dry weight }\left(\mathrm{g} . \mathrm{L}^{-1}\right)\end{array}$ & $\begin{array}{c}\text { Maximum lipase } \\
\text { activity/maximum } \\
\text { mycelial dry weight }\end{array}$ & $\begin{array}{c}\text { Lipase } \\
\text { Induction } \\
\text { factor }\end{array}$ \\
& & & $\begin{array}{c}\text { Specific lipase activity } \\
\left(\mathrm{U.g}^{-1}\right)\end{array}$ & \\
\hline Glucose & 1240 & 6.2 & 200 & 1 \\
Olive oil & 3800 & 6.7 & 567 & 3 \\
Gluc. + olive oil & 9500 & 15.3 & 620 & 7.7 \\
\hline
\end{tabular}

(a) Induction rate: ratio of specific activities with and without additional carbon source. 
in relation to the basal medium (BM). The presence of $1 \%$ glucose, although stimulating a 3-fold lipase activity in relation to $\mathrm{BM}$, abolished the enzyme induction produced by $1 \%$ olive oil. The results presented in Table 1 indicate a higher biomass production in $1 \%$ olive oil medium $\left(15.3 \mathrm{~g} . \mathrm{L}^{-1}\right)$ in relation to glucose or glucose/olive oil medium (6.7 and 10.7 g.L $\mathrm{L}^{-1}$, respectively). Our data shows similar lipase activities (in terms of Units per mg biomass) for both glucose and olive oil supplements. However, the presence of both supplements depresses lipase induction. Rapp (14) showed this effect with Fusarium oxysporum when mixtures of glucose and olive oil (both at 1\%) resulted in a peak of biomass at approx $100 \mathrm{~h}$ while lipase peaked at $220 \mathrm{~h}$. The effect of different concentrations of olive oil and peptone on lipase production was evaluated after 72 hours of cultivation (Fig. 1). At a peptone concentration of $3 \%(\mathrm{w} / \mathrm{v})$, the highest lipase activity of 10,500 U.L $L^{-1}$ was obtained in the media containing $0.5 \%$ (v/v) olive oil. Lower $(0.25 \%)$ and higher $(1 \%)$ oil concentrations decreased lipase production to 8,300 U.L ${ }^{-1}$ and 7,800 U.L. ${ }^{-1}$, respectively (Fig. 1A). Decreases in lipase production with increases in inducer concentrations have been noted $(11,3)$ for Aspergillus oryzae (soyabean oil) and Candida rugosa (olive oil). However, others have reported $(17,13)$ increased lipase production with increasing inducer concentrations for Penicillium citrinum (olive oil) and Candida rugosa (oleic acid). Pokorny et al. (12) showed that the addition of olive oil in concentrations between $0.5 \%$ and $2 \%$ increased the lipase production by Aspergillus niger to a maximum at $72 \mathrm{~h}$. The addition of olive oil to the basal medium at a concentration of $0.2 \%$ increased lipase activity by Torulopsis ernobii, but amounts of olive oil greater than $0.8 \%$ gave smaller increases (24). These authors suggest that the role of lipids in augmenting lipase production appears to be related to growth. These observation reinforce the constitutive and the biomass-linked lipase production by FS1 strain. Higher oil concentrations could be affecting the aeration rate of the culture and promoting a delay in mycelial growth and lipase production.

Further evidences for that biomass-linked lipase production are showed in the Fig. 1B, where a decrease in peptone concentration to half $(1.5 \% \mathrm{w} /$ v) promoted 2.5-times decrease in lipase activity after 72 hours of cultivation in BM containing $0.5 \%$ olive oil. Peptone concentration of $0.5 \%(\mathrm{w} / \mathrm{v})$ almost abolished lipase activity (Fig. 1B). This peptone- dependence was demonstrated for the lipase production by $F$. oxysporum f. sp. vasinfectum (14).

Batch fermentations were carried out in basal medium supplemented with $0.5 \%(\mathrm{v} / \mathrm{v})$ olive oil and $3 \%(\mathrm{w} / \mathrm{v})$ peptone for lipase production by FS1 strain (Fig. 2). A low lipase activity was observed until 48 hours of cultivation, at the moment that the culture entered into stationary phase of growth. However, it increased exponentially up to $96 \mathrm{~h}$ to a value of 9,500 U.L-1. The production of lipase is accompanied by an increase in the supernatant $\mathrm{pH}$ up to value of 8.3. Such $\mathrm{pH}$ increase was also observed during lipase production by Aspergillus oryzae (11). In spite of the media containing peptone, the FS1 strain produced low quantity of protease during the period of fermentation, that reached maximal activity at 72 hours of cultivation (500 U.L. $\left.\mathrm{L}^{-1}\right)$ and decreased thereafter (Fig. 2). Low protease activity should facilitate downstream process for lipase recovering (6).
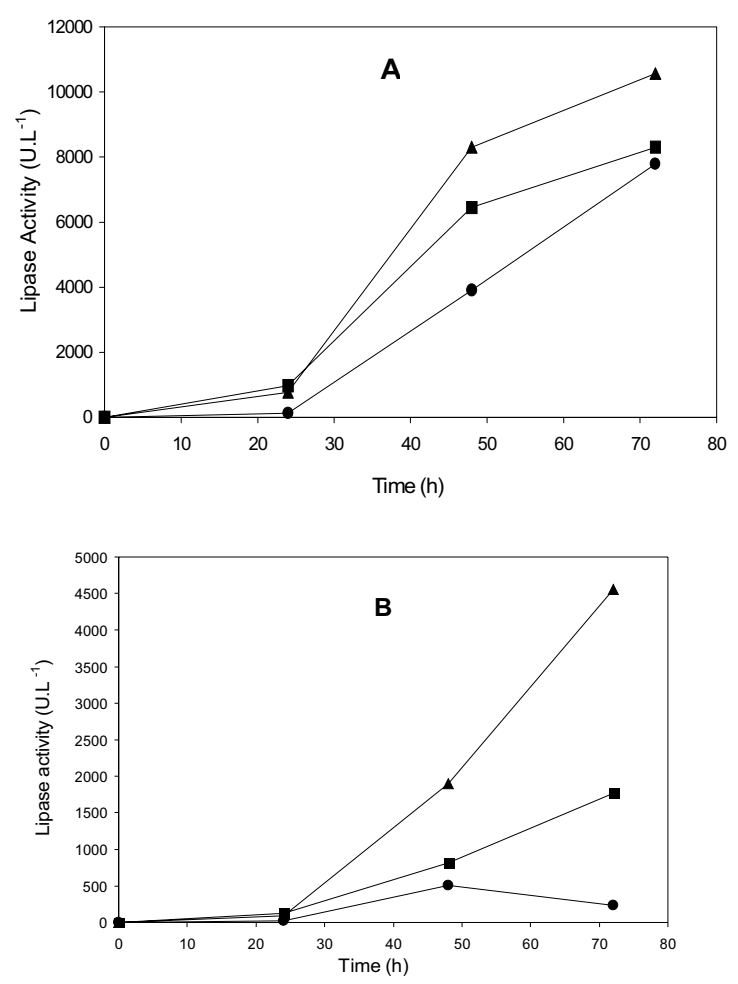

Figure 1. Effect of the olive oil and peptone concentration on lipase production by FS1 strain.(A) Medium containing 3\% (w/ v) peptone was supplemented with olive oil at concentrations (v/ v) of $0.25 \%(\mathbf{\square}), 0.5 \%(\mathbf{\Delta})$ and $1 \%(\mathbf{O})$; (B) Medium containing $0.5 \%(\mathrm{v} / \mathrm{v})$ olive oil was prepared with peptone at concentrations $(\mathrm{w} / \mathrm{v})$ of $0.5 \%(\mathbf{O}), 1.5 \%(\square)$ and $3 \%(\mathbf{O})$. Values are means of three experiments. 


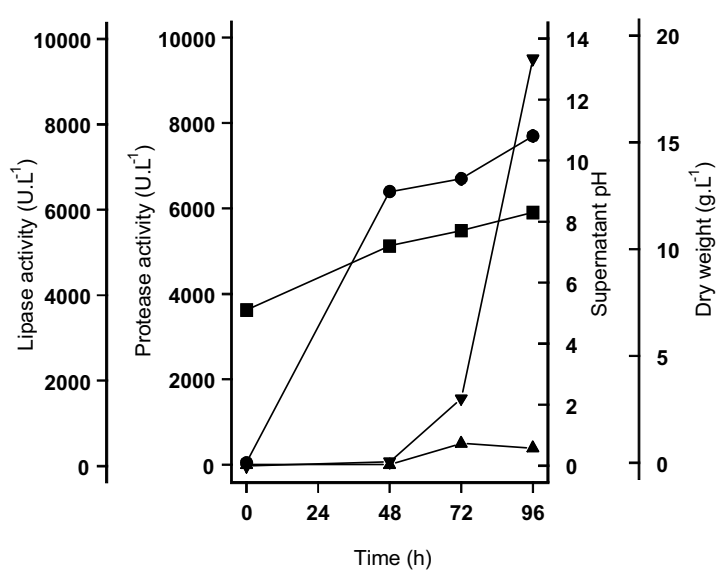

Figure 2. Batch fermentation of the FS1 strain in the medium containing $3 \%(\mathrm{w} / \mathrm{v})$ peptone and $0.5 \%(\mathrm{v} / \mathrm{v})$ olive oil $(120 \mathrm{rpm}$ at $28^{\circ} \mathrm{C}$ ). Values of lipase activity, $(\boldsymbol{\nabla})$ mycelial dry weight $(\mathbf{O})$, supernatant $\mathrm{pH}(\boldsymbol{\square})$ and protease activity $(\boldsymbol{\Delta})$ were taken in different period of cultivation. Values are means of three experiments.

\section{Effect of the $\mathrm{pH}$ and temperature on the lipase activity of Fusarium solani FS1 and stability}

The lipase activity was evaluated at different $\mathrm{pH}$ values at $25^{\circ} \mathrm{C}$ using pNPP as substrate (Fig. 3). The optimum activity for pNPP hydrolysis of $10,620 \mathrm{U}^{\mathrm{L}} \mathrm{L}^{-1}$ was reached at $\mathrm{pH} 8.6$ in $50 \mathrm{mM}$ tris- $\mathrm{HCl}$ buffer and $\mathrm{pH}$ values below 8.0 decreased lipase activity. Extracellular lipase of $F$. oxysporum f. sp. line and $F$. oxysporum $\mathrm{f}$. sp. vasinfectum showed optimum activity at $\mathrm{pH} 7.0$ (in $25 \mathrm{mM}$ Tris- $\mathrm{HCl}$ buffer, $\left.37^{\circ} \mathrm{C}\right)$ and at $\mathrm{pH}$ 5.8 (in $0.06 \mathrm{M}$ sodium phosphate, $35^{\circ} \mathrm{C}$ ), respectively $(8,14)$. Lipase mantained around $80 \%$ its initial activity when incubated for one hour at $\mathrm{pH}$ values between 7.2 and 8.6, with an decrease in lipase activity at $\mathrm{pH}$ beyond this range. The enzyme was more stable at pH 7.2 in tris-maleate buffer, despite its optimum activity at pH8.6 in tris-HCl buffer (Fig. 3). The incubations of the enzyme for $2 \mathrm{~h}$ and $4 \mathrm{~h}$ at $25^{\circ} \mathrm{C}$ in the $\mathrm{pH}$ range of 6.4 to 8.8 decreased lipase activity for the values around $40 \%$ and $30 \%$, respectively (Fig. $3)$. No lipase activity was observed after $24 \mathrm{~h}$ incubation at any $\mathrm{pH}$ value tested. This decrease in enzyme stability should be due to some denaturation effect, as well as to the presence of protease in the samples. Extracellular lipase of $F$. oxysporum f. sp. vasinfectum showed stability over the $\mathrm{pH}$ range of 4.0 to 10 during $1 \mathrm{~h}$ incubation at $30^{\circ} \mathrm{C}(14)$. On the other hand, others strains of $F$. oxysporum showed stability only at alkaline $\mathrm{pH}(15 ; 8)$.

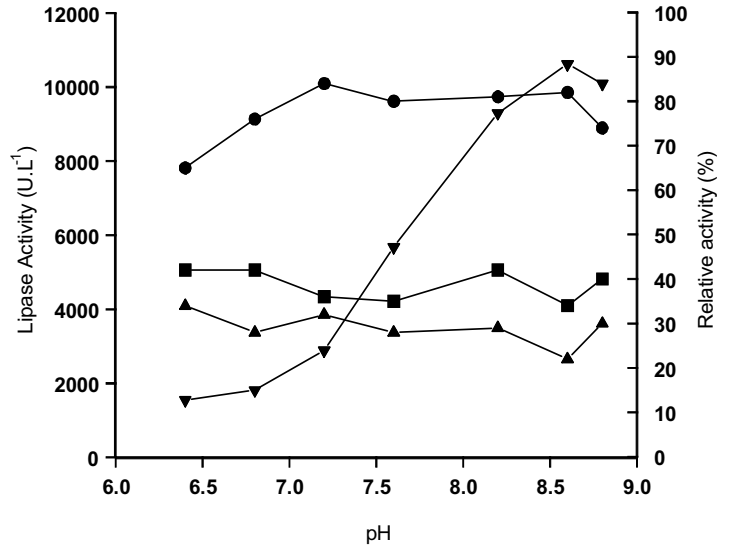

Figure 3. Effect of the pH on FS1 lipase activity and stability. Lipase activity was measured in reaction mixtures prepared with buffers at different $\mathrm{pH}$ values $(\boldsymbol{\nabla})$ after previous incubation of

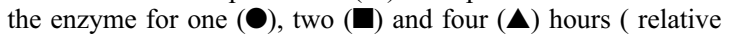
activity )at $25^{\circ} \mathrm{C}$ in the same buffers. Buffers were $50 \mathrm{mM}$ trismaleate (pH 5.4 to 7.8 ) and $50 \mathrm{mM}$ tris- $\mathrm{HCl}$ (pH 8.0 to 8.8).

Lipase presented two peaks of optimum temperature at $25^{\circ} \mathrm{C}$ and $45^{\circ} \mathrm{C}$ (Fig. 4). This behaviour of lipase activity from Fusarium solani FS1 may be indicative of the presence of isoenzymes. A considerable decrease in the lipolytic activity was observed for highest temperatures, reaching zero activity at $60^{\circ} \mathrm{C}$. Maximal stability of the enzyme was observed in the temperature range of $25^{\circ} \mathrm{C}$ to $30^{\circ} \mathrm{C}$ after its thermal exposure for $1 \mathrm{~h}$ (Fig. 4). Incubations above $40^{\circ} \mathrm{C}$ promoted inactivation of this enzyme. The lipase produced by $F$. oxysporum f. sp. line and $F$. oxysporum $\mathrm{f}$. sp. vasinfectum showed optimum activity at $42^{\circ} \mathrm{C}$ and $45^{\circ} \mathrm{C}$, respectively

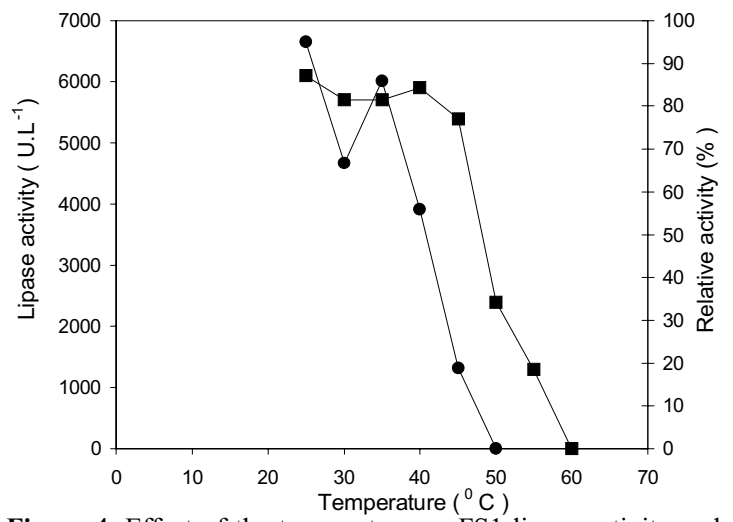

Figure 4. Effect of the temperature on FS1 lipase activity and thermal stability. Lipase activity was measured in $50 \mathrm{mM}$ tris$\mathrm{HCl} \mathrm{pH} 8.0$ over a range of temperature from $25^{\circ} \mathrm{C}$ to $60^{\circ} \mathrm{C}(\mathbf{\square})$ and after previous incubation of the supernatant mixtures for one hour in the temperatures indicated (0). 
$(8,14)$. Moreover, the lipases produced by both of the strains above were more thermostable than the FS1 lipase. The optimun temperatures were $25^{\circ} \mathrm{C}$ for A. oryzae (16), $37^{\circ} \mathrm{C}$ for C. cylindracea (16), and $40^{\circ} \mathrm{C}$ for Geotrichum candidum (21).

\section{Stability of the FS1 lipase in organic solvents}

Experiments presented in Fig. 5 demonstrate that 1-pentanol completely abolished lipase activity at $10 \%(\mathrm{v} / \mathrm{v})$, while acetone and n-propanol maintained $30 \%$ of activity under this condition. At $20 \%(\mathrm{v} / \mathrm{v})$, the last two solvents completely inhibited lipase activity. In contrast, n-hexane increased lipase activity to $170 \%$ of its initial activity at $40 \%(\mathrm{v} / \mathrm{v})$ solvent concentration (Fig. 5). A similar result was demonstrated when F. Oxysporum f. sp. vasinfectum lipase was incubated with n-hexane (14). On the other hand, lipase from Bacillus $s p$ was inhibited in the presence of n-hexane (20). This effect has been discussed by Rapp (14) as an increase of the reaction mixture emulsification by n-hexane, an waterimmiscible solvent, promoting the best contact between enzyme and substrate. The activity of lipase depends on the quality of an oil-water interface (4)

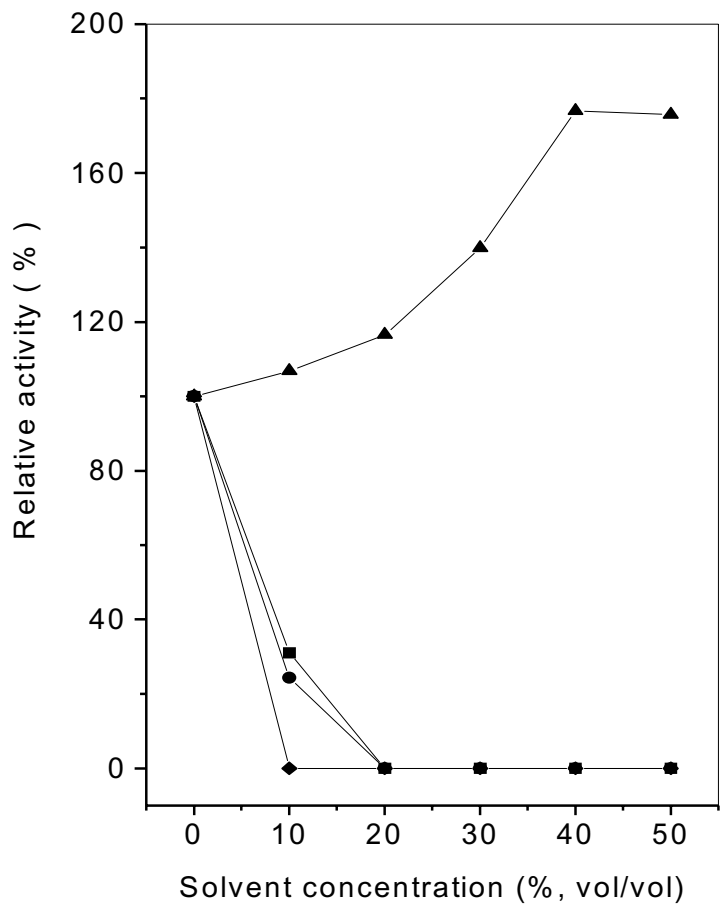

Figure 5. Effect of the organic solvent on activity of the FS1 lipase. The enzyme was incubated for one hour at $25^{\circ} \mathrm{C}$ with constant with different concentrations of acetone $(\boldsymbol{\square})$, n-propanol $(\bullet)$, n-hexane $(\boldsymbol{\Delta})$, 1-pentanol $(\bullet)$. and water-miscible organic solvents generally cause protein denaturation (1). In studies on the use of lipase for transesterification and synthesis of esters, the reactions have previously been carried out in media containing water-immiscible organic solvents and a small amount water, due to the fact that enzymes are less susceptible to denaturation in such systems (20). Since lipase from Fusarium solani FS1 has been shown to be stimulated by the addition of n-hexane, the enzyme might be useful for transesterification and ester synthesis. Experiments in flavour synthesis using FS1 lipase has been initiated in our laboratory with very promising results.

\section{RESUMO}

\section{Produção de lipase extracelular pelo fungo fitopatogênico Fusarium solani FS1}

Uma estirpe brasileira de Fusarium solani foi testada para produção de lipase em meio contendo peptona e óleo de oliva. O fungo produziu 10.500U.L $\mathrm{L}^{-1}$ de lipase após $72 \mathrm{~h}$ de incubação a $25^{\circ} \mathrm{C}$ e $120 \mathrm{rpm}$ em meio contendo $3 \%(\mathrm{p} / \mathrm{v})$ de peptona e $0,5 \%(\mathrm{v} / \mathrm{v})$ de óleo de oliva. A glicose $(1 \% \mathrm{w} / \mathrm{v})$ parece inibir o efeito estimulador do óleo de oliva. Concentrações de peptona abaixo de $3 \%(\mathrm{w} / \mathrm{v})$ reduziram a produção de lipase enquanto que o aumento na concentração de óleo de oliva acima de $0,5 \%(\mathrm{v} / \mathrm{v})$ não estimulou a produção da enzima. Ótima atividade lipásica foi alcançada em $\mathrm{pH}$ 8,6 e $30^{\circ} \mathrm{C}$ e uma boa estabilidade enzimática foi observada em $\mathrm{pH}$ variando de 7,6 a 8,6, mas a atividade caiu rapidamente à temperaturas acima de $50^{\circ} \mathrm{C}$. A atividade lipásica foi estimulada pela adição de nhexano à mistura de incubação, em contraste com a incubação em solventes orgânicos solúveis em água.

Palavras-chave: cinética enzimática, hidrólise de ésteres, lipase extracelular, Fusarium solani, pNPP.

\section{ACKNOWLEDGEMENTS}

This work was supported by grants from the following Brazilian agencies: Fundação de Apoio ao Desenvolvimento Científico do Estado de Pernambuco (FACEPE), Financiadora de Estudos e Projetos (FINEP), Banco do Nordeste do Brasil (BNB) and Programa de Apoio ao Desenvolvimento Científico e Tecnológico (PADCT/CNPq). 


\section{REFERENCES}

1. Abramowicz, D. A.; Keese, C. R. Enzymatic Transesterifications of carbonates in water restricted environments. Biotech. Bioeng. 33:2-149,1989.

2. Brockman, H. L. General feature of lipolysis in lipases:Reaction scheme interfacial structure and experimental approaches in Lipases. Borgstrom, B. \& Brockman, H. L.(eds.) Elsev. Sci. Publis., Amsterdam, 1984 p. $1-46$.

3. Camargo de Morais, M. M.; Morais Jr., M.A.; Melo, E. H. M.; Lima Filho, J. L. Production of extracellular lipase by a Candida rugosa strain isolated in Pernambuco, Brazil. Rev. Microbiol., 29: 134-137, 1998.

4. Desnuelle, P. The Lipases. In: The Enzymes.(eds)Boyer, P.D., New York Academic Press, 1972, p. 575-616.

5. Ginther, C. I. Sporulation and the production of serine protease and Cephamycin C by Streptomyces lactamdurans. Antimicrobial Agents and Chemotherapy, 15: 522-526, 1979.

6. Gordillo, M. A.; Obradors, N.; Montesinos, J. L.; Valero, F.; Lafuente, J.; Sóla, C. Stability studies and effect of the initial oleic acid concentration on lipase production by Candida rugosa. Appl. Microbiol. Biotechnol. 43: 38-41, 1995.

7. Hoshino, T.; Mizutani, A.; Shimizu, S.; Hidaka, H.; Yamane, T. Calcium ion regulates the release of lipase of Fusarium oxysporum. J. Biochem. (Tokyo) 110: 457-461, 1991.

8. Hoshino, T.; Sasaki, T.;Watanabe, Yuichi, W. Nagasawa, T.; Yamane, T. Purification and some characteristics of extracellular lipase from Fusarium oxysporum f.sp. lini. Biosc., Biotechnol. Biochem. 56: 660-664, 1992.

9. Macrae, A.R. Lipase-catalyzed interesterification of oils and fats. J. Am. Oil Chem. Soc. 60: 243-246, 1983.

10. Magolin, A.L. Enzymes in the synthesis of chiral drugs. Enz. Microbiol. Technol. 15: 266-280, 1993.

11. Ohnish, K.; Yoshida, Y.; Sekiguchi, J. Lipase production of Aspergillus oryzae. J. Ferment. Bioeng. 77: 490-495, 1994.

12. Pokorny D.; Friedrich J.; Cimerman A. Effect of nutritional factors on lipase biosynthesis by Aspergillus niger. Biotechnol. Lett. 16: 363-366, 1994.
13. Pimentel, M.C.B.; Krieger,N.; Coellho, L.C.C.B.; Fontana, J.O Melo, E.H.M.; Ledingham, W.M.; Lima Filho, J.L. Lipase from a Brazilian strain of Penicillium citrinum. Appl. Biochem. Biotechnol. 49: 59-73, 1994.

14. Rapp, P. Production, regulation and some properties of lipase activity from Fusarium oxysporum f. sp. vasinfectum. Enz. Microbiol. Technol. 17: 832-838, 1995.

15. Rubylone, N. Improvements in relating to an enzymatic, an detergent and a washing method. European patent, EPI30064B1.1984.

16. Seitz, E. W. Industrial application of microbial lipase:a review. J. Am. Oil Chem. Soc. 51: 12-16, 1974.

17. Shimada. Y.; Sugihara, A.; Nagao, T.; Tominaga, Y. Induction of Geotrichum candidum lipase by long-chain fatty acids. $J$. Fermentation Bioeng. 74: 77-80, 1992.

18. Sonnet, P.E. Lipase selectivities. J. Am. Oil Chem. Soc. 65: 900-904, 1988.

19. Stamatis, H.; Xenakis; A.; Kolisis, F.N. Enantiomeric selectivity of a lipase from Penicillium simplicissimum in the esterification of menthol in microemulsions. Biotechnol. Lett. 15: 471-476. 1993.

20. Sugihara, A.; Tani, T.; and Tominaga, Y. Purification and Characterization of a novel thermostable lipase from Bacillus sp. J. Biochem. 109: 211-216. 1991.

21. Tsujisaka, Y.; Iwai, M.; Fukumoto, J.; Okamoto, Y. Induced formation of lipase by Geotrichum candidum Agr. Biol. Chem. 37: 837-842, 1973.

22. Vulfson, E. Industrial application of lipases. In: Lipases: Their structure, Biochemistry and Application, Wooley, P. \& Petersen, S.B. (eds) Cambridge University Press,G.B. 1994, p. 271-288

23. Winkler, U. K.; Stuckmann M., Glycogen, hyaluronate and some other polysaccharides great enhance the formation of exolipase by Serratia marcescens. J. Bacteriol. 138: $663-$ 670, 1979.

24. Yoshida, F.; Motai, H. and Ichishima, E. Effect of lipid materials on the production of lipase by Torulopsis ernobii. Appl. Microbiol. 16: 845-847, 1968. 